\title{
Association of promoter methylation with histologic type and pleural indentation in non-small cell lung cancer (NSCLC)
}

Meiju $\mathrm{Ji}^{1 \dagger}$, Yong Zhang ${ }^{2 \dagger}$, Bingyin Shi ${ }^{1}$ and Peng Hou ${ }^{1 *}$

\begin{abstract}
Background: Lung cancer is a major cause of death worldwide. Gene promoter methylation is a major inactivation mechanism of tumor-related genes, some of which can be served as a biomarker for early diagnosis and prognosis evaluation of lung cancer.

Methods: We determined the promoter methylation of 6 genes using quantitative methylation-specific PCR (QMSP) technique in 96 clinically well-characterized non-small cell lung cancer (NSCLC).

Results: Highly frequent promoter methylation was found in NSCLC. With 100\% diagnostic specificity, high sensitivity, ranging from 44.9 to $84.1 \%$, was found for each of the 6 genes. Our data also showed that promoter methylation was closely associated with histologic type. Most of genes were more frequently methylated in squamous cell carcinomas (SCC) compared to adenocarcinomas (ADC). Moreover, promoter methylation significantly increased the risk of pleural indentation in NSCLC.

Conclusion: Our findings provided evidences that multiple genes were aberrantly methylated in lung tumorigenesis, and demonstrated the promoter methylation was closely associated with clinicopathologic characteristics of NSCLC. More importantly, we first revealed promoter methylation may be served as a potentially increased risk factor for pleural indentation of NSCLC patients.
\end{abstract}

\section{Background}

Lung cancer is a leading cause of cancer death worldwide, accounting for $30 \%$ of all cancer-related deaths [1]. The 5-year survival rate between 1996-2004 is $16 \%$ significantly lower than that of other major cancers [2]. Owing to the rapid industrialization and increase in the smoking consumption in society, lung cancer presents as the number one cancer type of threats in China [3]. Epidemiological evidence has documented that approximately 41.8 men and 19.3 women per 100,000 Chinese individuals died of lung cancer in 2005 [4]. Lung cancer is generally classified into two major histological categories, small cell lung cancer (SCLC) and non-small cell lung cancer (NSCLC). The latter accounts for approximately $85 \%$ of lung cancer [2]. Approximately $25-33 \%$ of

\footnotetext{
* Correspondence: phou@mail.xjtu.edu.cn

+ Contributed equally

'Department of Endocrinology, The First Affiliated Hospital of Xi'an Jiaotong University College of Medicine, Xi'an 710061, the People's Republic of China Full list of author information is available at the end of the article
}

NSCLC patients present with stage I or II disease, which permits surgical resection with curative intent. However, despite surgery, approximately $30-40 \%$ of patients with NSCLC who have discrete lesions and histologically negative lymph nodes die of recurrent disease [5]. Despite the fact that the cause of most lung cancer is well know, the disease has proven difficult to diagnosis early and treat successfully, reflecting limited advances in our understanding of the molecular mechanisms underlying lung carcinogenesis and individual susceptibility to lung cancer.

In addition to genetic factors [6-8], epigenetic alterations play an important role in lung cancer development and result in changes in gene function [9]. DNA methylation is an epigenetic event whose pattern is altered frequently in a wide variety of human cancers, including promoter-specific hypermethylation as well as genomewide hypomethylation $[10,11]$. Gene promoter hypermethylation is among the earliest and most common

\section{Biomed Central}


alterations in human cancers, including NSCLC, which leads to gene silencing and inactivation $[12,13]$.

In the present study, we sought to identify DNA methylation profiles in NSCLC and their association with known or suspected cancer risk factors. For this, we used quantitative methylation-specific PCR (Q-MSP) to evaluate promoter methylation of a panel of cancerassociated genes in a large cohort of clinically well-characterized NSCLC samples, including calcitonin-related polypeptide alpha (CALCA), E-cadherin $(C D H 1)$, deathassociated protein kinase 1 (DAPK1), iroquois homeobox 1 (IRX2), TIMP metallopeptidase inhibitor 3 (TIMP3), and paired box 6 (PAX6). These genes were potentially important in NSCLC, some of which have been assessed by others but some of which have not been evaluated previously.

\section{Methods}

\section{Study subjects and DNA isolation}

Ninety-six tumor samples and 15 nonmalignant lung samples were obtained from NSCLC patients who underwent curative resection at the First Affiliated Hospital of China Medical University, with approval by the institutional review board of the Hospital. None of these patients received chemotherapy and radiotherapy before the surgery. Informed consent was obtained from each patient before the surgery. All of the samples were histologically examined by a pathologist at Department of Pathology of the Hospital to identify the type and other clinical characteristics of the tumors. The clinical files of these patients are shown in Table 1. Samples were prepared and genomic DNA was isolated from paraffinembedded samples as previously described [14]. Briefly, after a treatment for overnight at room temperature with xylene to remove pareffin, tissues were digested with $1 \%$ sodium dodecyl sulfate (SDS) and $0.5 \mathrm{mg} / \mathrm{ml}$ proteinase $\mathrm{K}$ at $48^{\circ} \mathrm{C}$ for $48 \mathrm{~h}$, with addition of several spiking aliquots of concentrated proteinase $\mathrm{K}$ to faciliate digestion. DNA was subsequently isolated using standard phenol/chloroform protocol, and was dissolved in distilled water and stored at $-80^{\circ} \mathrm{C}$ until use.

\section{Sodium bisulfite treatment}

DNA from the primary tumors and nonmalignant lung samples was subjected to bisulfite treatment as described previously [14]. Briefly, a final volume of $20 \mu \mathrm{l}$ of $\mathrm{H}_{2} \mathrm{O}$ containing 1-2 $\mu \mathrm{g}$ genomic DNA, $10 \mu \mathrm{g}$ salmon sperm DNA, and $0.3 \mathrm{M} \mathrm{NaOH}$ was incubated at $50^{\circ} \mathrm{C}$ for 20 min to denature the DNA. The mixture was then incubated for $2-3 \mathrm{~h}$ at $70^{\circ} \mathrm{C}$ in $500 \mu \mathrm{l}$ of a freshly prepared solution containing $3 \mathrm{M}$ sodium bisulfite (Sigma, Saint Louis, MO), $10 \mathrm{mM}$ hydroquinone (Sigma, Saint Louis, MO). Subsequently, the DNA was recovered by a Wizard DNA Clean-Up System (Promega Corp.,
Table 1 Clinicopathologic characteristics of NSCLC cases

\begin{tabular}{|c|c|}
\hline Characteristics & No. of patients (\%) \\
\hline \multicolumn{2}{|l|}{ Gender } \\
\hline Male & $66(69)$ \\
\hline Female & $30(31)$ \\
\hline Age (mean years \pm S.D.) & $58.9 \pm 9.2$ \\
\hline$\leq 60$ & $56(58)$ \\
\hline$>60$ & $40(42)$ \\
\hline \multicolumn{2}{|l|}{ Smoking history (pack-years) } \\
\hline 0 & $30(31)$ \\
\hline $1-39$ & $35(37)$ \\
\hline$\geq 40$ & $31(32)$ \\
\hline Tumor size (mean $\mathrm{cm} \pm$ S.D.) & $3.9 \pm 1.7$ \\
\hline $1-3$ & $37(38)$ \\
\hline $3-5$ & $44(46)$ \\
\hline$>5$ & $15(16)$ \\
\hline \multicolumn{2}{|l|}{ Histologic type } \\
\hline Adenocarcinoma (ADC) & $30(31)$ \\
\hline Brochoalveplar cell (BAC) & $6(6)$ \\
\hline Adenocarcinoma (non-BAC) & $24(25)$ \\
\hline Squamous (SCC) & $66(69)$ \\
\hline \multicolumn{2}{|l|}{ Histologic stage } \\
\hline I & $54(56)$ \\
\hline$\|$ & $32(34)$ \\
\hline III & $10(10)$ \\
\hline \multicolumn{2}{|l|}{ Lymph node metastasis } \\
\hline No & $70(73)$ \\
\hline Yes & $26(27)$ \\
\hline \multicolumn{2}{|l|}{ Pleural indentation } \\
\hline No & $75(78)$ \\
\hline Yes & $21(22)$ \\
\hline \multicolumn{2}{|l|}{ Invasion or Adhesion } \\
\hline No & $65(68)$ \\
\hline Yes & $31(32)$ \\
\hline
\end{tabular}

Madison, WI) following the instructions of the manufacturer, followed by ethanol precipitation, and resuspension in $30 \mu \mathrm{l}$ of deionized $\mathrm{H}_{2} \mathrm{O}$. After bisulfite processing, all unmethylated cytosine residues converted to uracil, whereas the methylated cytosine residues remained unchanged. Bisulfited-modified DNA samples were stored at $-80^{\circ} \mathrm{C}$ until use.

\section{Quantitative methylation-specific PCR (Q-MSP) analysis}

After sodium bisulfite conversion, the methylation analysis was performed by the fluorescence-based quantitative PCR assay as described previously [14]. Briefly, the Q-MSP amplification was carried out in triplicate for each samples in a final reaction mixture of $20 \mu \mathrm{l}$ containing $3 \mu \mathrm{l}$ bisulfite-treated DNA, $600 \mathrm{nM}$ each primer, 
$200 \mathrm{nM}$ TaqMan probe, $5.5 \mathrm{mM} \mathrm{MgCl} 2$, $1 \mathrm{U}$ platinum Taq polymerase, $200 \mu \mathrm{M}$ each of deoxyguanosine triphosphate, and $2 \%$ Rox reference. After an initial denaturation step at $95^{\circ} \mathrm{C}$ for $2 \mathrm{~min}, 40$ cylces of $15 \mathrm{sec}$ at $95^{\circ} \mathrm{C}$ and $60 \mathrm{sec}$ at $60^{\circ} \mathrm{C}$ for annealing and extension were run using an ABI 7500 Fast Real-Time PCR System (Foster City, CA). Normal leukocyte DNA was methylated in vitro with Sss I methylase (New Engliand Biolabs, Beverly, MA) to generate completely methylated DNA as a positive control. Each plate contained triplicate samples and multiple water blanks, as well as serial dilutions of positive methylated control to construct the standard curve. The internal reference gene $\beta$-actin was used to normalize the amount of input DNA. The primers and TaqMan probes used in the present study were presented in Table 2 . The relative degree of methylation of each sample was calculated using the method described previously [15].

\section{Statistical analysis}

Promoter methylation was considered present if the ratio was above a certain cut-off value. The relative level of methylation varied significantly among the 6 genes and therefore cut-off points were studied for each gene individually. To set up cut-off value for each gene for detection of NSCLC, we used the Medcalc Software (MedCalc Software bvba, Belgium) to construct receiver operating characteristic (ROC) curves. The area under the curve of ROC curve is a measure of the ability of a continuous marker to accurately classify tumor and non-tumor tissue. Such a curve is a plot of sensitivity $v s .1$ minus specificity values associated with all dichotomous markers that can be formed by varying the value threshold (or cut-off value) used to designate a marker "positive". Factors associated with patients and tumor characteristics were assessed univariately with chi-square tests for trend and logistic regression. In the final analysis, multivariable adjustments were made to adjust for the potentially confounding effects of smoking history, histologic type, lymph node metastasis, and pleural indentation. $P<$ 0.05 was considered to be statistically significant. All statistical analyses were performed using the SPSS statistical package (11.5, Chicago, IL, USA).

\section{Results \\ Demographics}

In the present study, we chose genes which were potentially important in NSCLC and determined the promoter methylation of these 6 genes using Q-MSP assay in 96 well-characterized NSCLC patients. As shown in Table 1 the mean age of the 96 NSCLC cases was 58.9 years. Males were more than females (69\% vs. 31\%). Sixty-nine percent of patients reported a history of smoking, with $32 \%$ reporting at least 40 life-time pack-years of smoking. Ninety percent of NSCLC cases had surgical stage I or II disease and $84 \%$ had tumors $<5 \mathrm{~cm}$. By histology, $31 \%$ of tumors were adenocarcinomas (ADC), including $6 \%$ bronchioloalveolar carcinomas (BAC) and 25\% nonBAC adenocarcinomas, and $69 \%$ were squamous cell carcinomas (SCC). The cases with lymph node metastasis, pleural indentation and invasion or adhesion were in 26/96 (27\%), 21/96 (22\%), and 31/96 (32\%), respectively.

\section{Frequent promoter methylation in NSCLC}

We examined promoter methylation of CALCA, CDH1, DAPK1, IRX2, TIMP3, and PAX6 using Q-MSP in a cohort of 96 NSCLC. As shown in Figure 1, the overall methylation level of each gene was higher in tumor tissues than in nonmalignant lung tissues. Among the 6 genes examined, statistical significances were observed in CALCA $(P<0.01), C D H 1(P<0.01)$, and PAX6 $(P<$ $0.001)$. We set up appropriate cut-off values to distinguish NSCLC from nonmalignant lung tissues, and determine diagnostic sensitivity and specificity. As shown in Figure 2, with 100\% diagnostic specificity for each of the 6 genes, the sensitivity of CALCA, CDH1, DAPK1, IRX2, TIMP3, and PAX6 was $69.2 \%, 45.8 \%$, $84.1 \%, 52.3 \%, 44.9 \%$, and $75.7 \%$, respectively.

\section{Association of promoter methylaton with clinicopathological charactristics of NSCLC}

Among all clinicopathologic characteristics, methylation levels varied substantially by histologic type (Table 3 ).

Table 2 Quantitative methylation-specific PCR primer and TaqMan probe sequences used in the present study

\begin{tabular}{|c|c|c|c|}
\hline Genes & Forward primer sequence $\left(5^{\prime} \rightarrow 3^{\prime}\right)$ & Probe sequence $\left(5^{\prime} \rightarrow 3^{\prime}\right)$ & Reverse primer sequence $\left(5^{\prime} \rightarrow 3^{\prime}\right)$ \\
\hline ALCA & TTATGAGGGTGACG & 6FAM-ATTCCGCCAATACACAACAACCAATAAACG-TAMRA & TTCCCGCCGCTATAAATCG \\
\hline $\mathrm{CDH1}$ & AATTTAGGTTAGAGGGTTATCGCGT & 6FAM-CGCCCACCCGACCTCGCAT-TAMRA & TCCCCAAAACGAAACTAACGAC \\
\hline DAPK1 & GGATAGTCGGATCGAGTTAACGTC & 6FAM-TTCGGTAATTCGTAGCGGTAGGGTTTGG-TAMRA & CCCTCCCAAACGCCGA \\
\hline IRX2 & GCGGGTCGTTTAGGTTAGTATTCG & 6FAM-CCCTCCATCCACGCCCGACCGAAA-TAMRA & CGCCGAACAACGAACAA \\
\hline TIMP3 & GCGTCGGAGGTTAAGGTTGTT & 6FAM-AACTCGCTCGCCCGCCGAA-TAMRA & CTCTCCAAAATTACCGTACGCG \\
\hline PAX6 & ATATAGGACGGCGGTTTAGGTTG & 6FAM-CCCAAAATCCGACCGACTCCAACCCCTA-TAMRA & TTCCGACCGAACGAAAACCTAC \\
\hline -Actin & TGGTGATGGAGGAGGTTTAGTAAGT & 6FAM-ACCACCACCCAACACACAATAACAAACACA-TAMRA & AACCAATAAAACCTACTCСTCCCTTAA \\
\hline
\end{tabular}




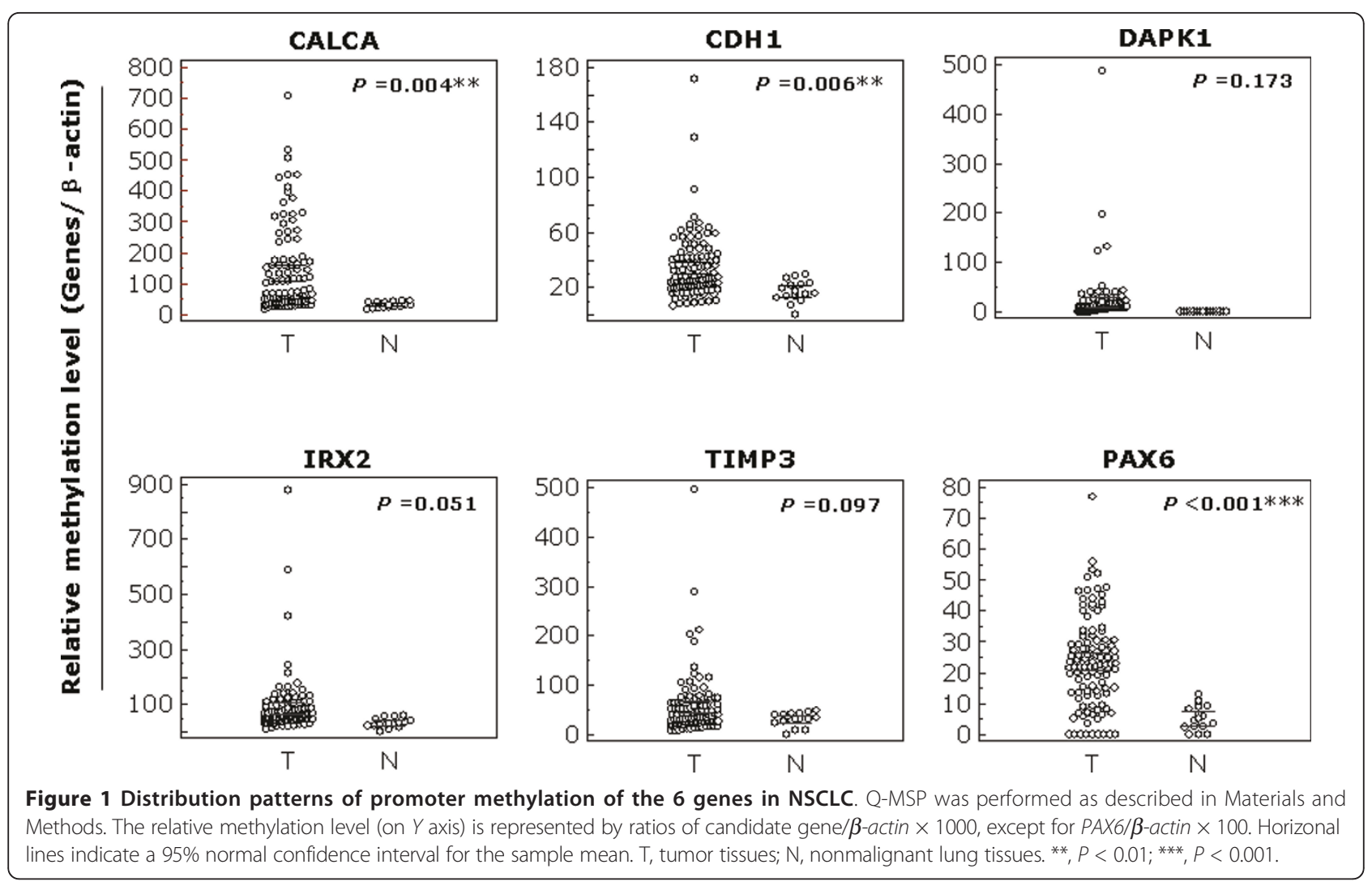

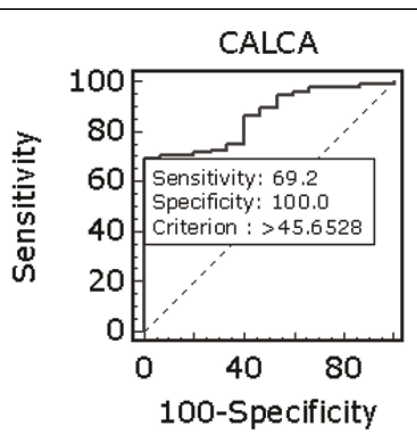

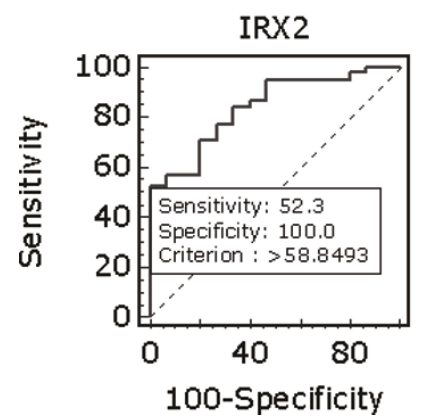

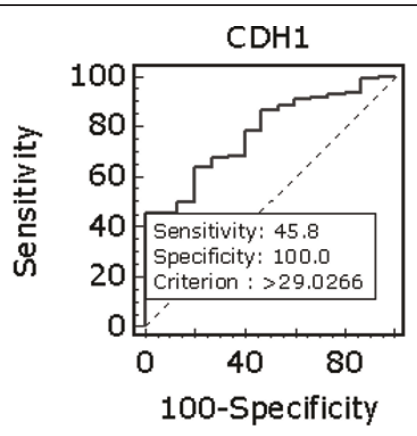

TIMP 3

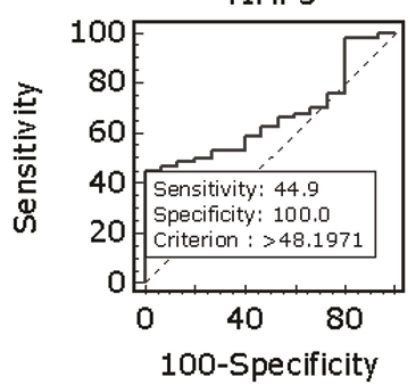

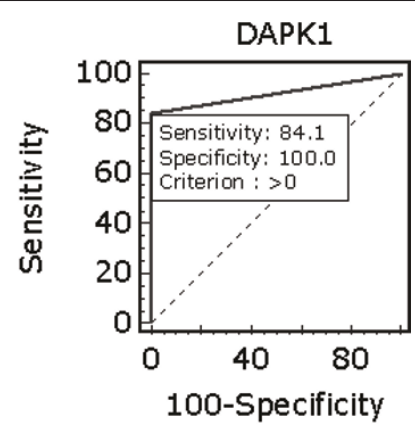

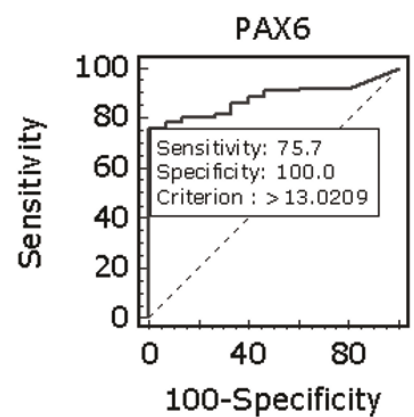

Figure 2 Receiver operating characteristic (ROC) curves for the 6 genes in NSCLC. All tumor and nonmalignant lung tissues for which there was complete DNA methylation data were used for the analyses. The ROC curves plot sensitivity vs. 100-specificity. The determined cut-off values for CALCA, CDH1, DAPK1, IRX2, TIMP3, and PAX6 were 45.7, 29.0, 0, 58.8, 48.2, and 13.0, respectively. 
Methylation level of most of genes was higher in SCC than in ADC, particularly in $C D H 1$ gene $(P<0.05)$ (Table 3$)$. There was a significant difference in the methylation level of $D A P K 1$ gene between lymph node metastasis group and nonmetastasis group (40.3 \pm 100.5 in the former $v s .12 .3 \pm 18.5$ in the latter, $P<0.05$ ) (Table 3). The methylation level of CALCA gene was significant higher in the patients with invasion or adhesion compared with patients without invasion or adhesion $(174.5 \pm 160$ vs. $115.1 \pm 122.5, P<0.05)$ (Table 3$)$. The methylation level of CALCA gene was found to be significantly associated with smoking history (155.2 \pm 150.2 in smokers vs. $89.6 \pm 92.7$ in non-smokers, $P<$ 0.05 ) (Table 3). Our data showed that the methylation level of most of genes was not associated with quantity of cigarette smoking (Pack-years) (Additional file 1). Of note, there was a significant difference in the methylation level of PAX6 gene between patients with age $>60$ years and $\leq 60$ years $(28.6 \pm 16.2$ in the former $v s .20 .2$ \pm 12.4 in the latter, $P<0.05$ ). In addition, the methylation level of $C A L C A$ gene was also found to be significantly associated with tumor stage $(217.7 \pm 186.7$ in patients with histoligical satge $\geq$ III vs. $125 \pm 129$ in patients with histological stage $<$ III, $P<0.05$ ) (Additional file 1). The methylation level of several genes was associated with increased tumor size, including CALCA, DAPK1, IRX2, and TIMP3 genes, although these associations did not reach statistical difference (Additional file 1).
In univariate analyses, the promoter methylation of most of genes was more frequent in SCC compared to ADC, particularly in $C D H 1(\mathrm{OR}=2.63,95 \% \mathrm{CI}=1.05$ 6.60), DAPK1 (OR $=6.64,95 \% \mathrm{CI}=1.85-23.8), I R X 2$ $(\mathrm{OR}=2.89,95 \% \mathrm{CI}=1.17-7.13)$, and TIMP3 $(\mathrm{OR}=$ 2.51, 95\% CI $=1.01-6.21$ ) (Table 4 ). In addition, methylation of $C A L C A(\mathrm{OR}=2.13,95 \% \mathrm{CI}=1.01-4.47)$ and TIMP3 (OR $=1.88,95 \% \mathrm{CI}=1.01-3.49)$ was significantly associated with histologic stage (Table 4). However, there was not significant association between promoter methylation and other clinocopathologic characteristics, including gender, age, smoking history, quantity of cigarette smoking, tumor size, lymph node metastasis, pleural indentation, and invasion or adhesion (Table 4). In order to assess the independent associations between promoter methylation and smoking history, histologic type, lymph node metastasis, and pleural indentation, we conducted multiple multivariable logistic regressions (Table 5). In multivariable analyses adjusting for potential false discovery rate associated with multiple comparisons (6 different models), methylation of most of genes ramained associated with histologic type. The promoter methylation of $C D H 1(\mathrm{OR}=6.77,95 \% \mathrm{CI}=$ 1.71-26.8), DAPK1 (OR = 10.7, 95\% CI = 2.16-52.6), IRX2 $(\mathrm{OR}=6.38,95 \% \mathrm{CI}=1.17-23.0)$, and TIMP3 $(\mathrm{OR}=3.37,95 \% \mathrm{CI}=1.03-11.0)$ genes was significant more likely in SCC compared to ADC (Table 5). However, after adjustment for smoking history, histologic type, and lymph node metastasis, the promoter methylaton of each

Table 3 Association of the level of promoter methylation with clinicopathologic charactristics of NSCLC

\begin{tabular}{|c|c|c|c|c|c|c|c|c|c|}
\hline \multirow{3}{*}{ Genes } & \multicolumn{3}{|c|}{ Gender $(n=96)$} & \multicolumn{3}{|c|}{ Histologic type $(n=96)$} & \multicolumn{3}{|c|}{ Smoking history $(n=96)$} \\
\hline & Female & Male & \multirow[t]{2}{*}{$P$} & SCC & ADC & \multirow[t]{2}{*}{$P$} & $\mathrm{Y}$ & $\mathbf{N}$ & \multirow[t]{2}{*}{$P$} \\
\hline & $(n=30)$ & $(n=66)$ & & $(n=66)$ & $(n=30)$ & & $(n=66)$ & $(n=30)$ & \\
\hline CALCA & $145.0 \pm 149.6$ & $112.1 \pm 106.5$ & 0.28 & $152.1 \pm 152.1$ & $96.4 \pm 90.6$ & 0.07 & $155.2 \pm 150.2$ & $89.6 \pm 92.7$ & $0.03^{*}$ \\
\hline $\mathrm{CDH1}$ & $33.1 \pm 18.7$ & $31.5 \pm 21.2$ & 0.71 & $35.4 \pm 19.2$ & $26.3 \pm 18.6$ & $0.03^{*}$ & $32.2 \pm 18.7$ & $33.4 \pm 21.3$ & 0.77 \\
\hline DAPK1 & $18.5 \pm 59.6$ & $23 \pm 45.2$ & 0.71 & $26.2 \pm 65.8$ & $5.9 \pm 7.6$ & 0.09 & $17.4 \pm 59.6$ & $25.4 \pm 45.2$ & 0.52 \\
\hline $\operatorname{IRX2}$ & $96.4 \pm 131.5$ & $63.9 \pm 34.8$ & 0.19 & $92.3 \pm 115.7$ & $72.9 \pm 103.6$ & 0.43 & $95.3 \pm 132.1$ & $66.3 \pm 36.1$ & 0.24 \\
\hline TIMP3 & $60.5 \pm 72.8$ & $50.9 \pm 39.1$ & 0.50 & $64.9 \pm 71.7$ & $41.3 \pm 39.8$ & 0.09 & $61.5 \pm 72.8$ & $48.8 \pm 38.9$ & 0.37 \\
\hline PAX6 & $23.4 \pm 15.1$ & $24.2 \pm 13.8$ & 0.78 & $24.0 \pm 15.5$ & $23.1 \pm 12.8$ & 0.79 & $23.9 \pm 15.6$ & $23.3 \pm 12.6$ & 0.85 \\
\hline \multirow[t]{3}{*}{ Genes } & \multicolumn{3}{|c|}{ Lymph node metastasis $(n=96)$} & \multicolumn{3}{|c|}{ Pleural indentation $(n=96)$} & \multicolumn{3}{|c|}{ Invasion or Adhesion $(n=96)$} \\
\hline & $\mathrm{Y}$ & $\mathbf{N}$ & $P$ & $\mathrm{Y}$ & $\mathrm{N}$ & $P$ & $Y$ & $\mathrm{~N}$ & $P$ \\
\hline & $(n=26)$ & $(n=70)$ & & $(n=21)$ & $(n=75)$ & & $(n=31)$ & $(n=65)$ & \\
\hline CALCA & $175.7 \pm 175.1$ & $119.5 \pm 119.1$ & 0.08 & $129.9 \pm 132.5$ & $136 \pm 140.2$ & 0.86 & $174.5 \pm 160$ & $115.1 \pm 122.5$ & $0.048^{*}$ \\
\hline $\mathrm{CDH} 1$ & $31.0 \pm 13.9$ & $33.1 \pm 21.2$ & 0.64 & $35.3 \pm 21.2$ & $31.8 \pm 18.9$ & 0.47 & $30.7 \pm 16.6$ & $33.5 \pm 20.7$ & 0.52 \\
\hline DAPK1 & $40.3 \pm 100.5$ & $12.3 \pm 18.5$ & $0.03^{*}$ & $12.4 \pm 11.9$ & $21.9 \pm 62.3$ & 0.49 & $10.9 \pm 10.6$ & $24.2 \pm 66.6$ & 0.27 \\
\hline$I R X 2$ & $42.7 \pm 51$ & $91.2 \pm 127.2$ & 0.47 & $73.1 \pm 38.4$ & $89.9 \pm 124.9$ & 0.54 & $71.8 \pm 48.3$ & $93.1 \pm 131.6$ & 0.38 \\
\hline TIMP3 & $69.3 \pm 91$ & $53.2 \pm 51$ & 0.28 & $53.9 \pm 42.9$ & $58.6 \pm 69.2$ & 0.77 & $52.7 \pm 53.1$ & $59.8 \pm 69.1$ & 0.61 \\
\hline PAX6 & $23.2 \pm 14.2$ & $23.9 \pm 14.9$ & 0.83 & $25.2 \pm 13.9$ & $23.3 \pm 14.9$ & 0.59 & $25.8 \pm 15.7$ & $22.7 \pm 14.1$ & 0.32 \\
\hline
\end{tabular}


Table 4 Promoter methylation in NSCLC-univariate associations with clinicopathologic characteristics (OR ${ }^{\dagger}$ and $95 \%$ Cl)

\begin{tabular}{cccccc}
\hline Genes & Male vs. Female & Age (per 10 years) & Smoking history & Pack-years $^{1}$ & SCC vs. ADC \\
\hline CALCA & $0.73(0.28-1.90)$ & $0.94(0.58-1.52)$ & $1.43(0.57-3.57)$ & $0.88(0.51-1.51)$ & $2.21(0.89-5.47)$ \\
\hline CDH1 & $2.13(0.86-5.22)$ & $0.83(0.53-1.30)$ & $1.41(0.59-3.39)$ & $0.91(0.55-1.50)$ & $2.63(1.05-6.60)^{*}$ \\
\hline DAPK1 & $1.45(0.43-4.87)$ & $1.16(0.60-2.24)$ & $2.11(0.64-6.92)$ & $1.83(0.84-3.98)$ & $6.64(1.85-23.8)^{*}$ \\
\hline IRX2 & $1.29(0.54-3.06)$ & $0.76(0.48-1.19)$ & $1.06(0.45-2.52)$ & $0.91(0.55-1.50)$ & $2.89(1.17-7.13)^{*}$ \\
\hline TIMP3 & $1.09(0.46-2.60)$ & $1.09(0.70-1.71)$ & $1.09(0.46-2.60)$ & $1.27(0.76-2.11)$ & $2.51(1.01-6.21)^{*}$ \\
\hline PAX6 & $1.04(0.37-2.88)$ & $1.19(0.70-2.03)$ & $0.78(0.27-2.25)$ & $0.93(0.51-1.69)$ & $1.04(0.37-2.88)$ \\
\hline Genes & Tumor size ${ }^{2}$ & Lymph node metastasis & Pleural indentation & Invasion or Adhesion & Histologic stage $^{\mathbf{3}}$ \\
\hline CALCA & $1.01(0.55-1.88)$ & $1.74(0.62-4.91)$ & $1.18(0.41-3.41)$ & $2.44(0.88-6.79)$ & $2.13(1.01-4.47)^{*}$ \\
\hline CDH1 & $1.20(0.67-2.13)$ & $1.02(0.41-2.51)$ & $1.79(0.67-4.76)$ & $0.96(0.41-2.27)$ & $1.11(0.62-2.02)$ \\
\hline DAPK1 & $1.81(0.72-4.54)$ & $5.17(0.64-41.95)$ & $1.63(0.33-8.02)$ & $1.70(0.43-6.67)$ & $1.24(0.50-3.08)$ \\
\hline IRX2 & $1.57(0.88-2.83)$ & $1.17(0.47-2.88)$ & $1.37(0.52-3.63)$ & $0.86(0.36-2.01)$ & $1.14(0.63-2.07)$ \\
\hline TIMP3 & $1.67(0.92-3.01)$ & $2.05(0.82-5.10)$ & $1.16(0.44-3.05)$ & $0.69(0.29-1.66)$ & $1.88(1.01-3.49)^{*}$ \\
\hline PAX6 & $0.78(0.40-1.54)$ & $0.74(0.26-2.09)$ & $2.04(0.54-7.69)$ & $1.84(0.61-5.56)$ & $1.76(0.79-3.93)$ \\
\hline DR 0 dds & & & & &
\end{tabular}

† OR: odds ratio with $95 \%$ confidence interval.

1 Pack-years $(0 ;>0$ and $<40 ; \geq 40)$.

2 Tumor size ( $>1$ and $\leq 3 ;>3$ and $\leq 5 ;>5$ ).

3 Histologic stage $(\mathbf{l} ; \mathrm{ll} ; \mathrm{III})$.

* Significant at $P<0.05$.

gene was more frequent in patients with pleural indentation compared with without pleural indentation (Table 5), particularly in $C D H 1(\mathrm{OR}=5.27,95 \% \mathrm{CI}=1.27-21.9)$, DAPK1 $(\mathrm{OR}=6.98,95 \% \mathrm{CI}=1.06-45.8)$, and IRX2 (OR = $3.89,95 \% \mathrm{CI}=1.01-15.0)$ genes, suggesting that promoter methylation of these genes may be a potential risk of pleural indentation in NSCLC.

\section{Discussion}

We assessed the promoter methylation of the 6 genes in a large cohort of well-characterized NSCLC subjects using Q-MSP technique in the present study, including CALCA, CDH1, DAPK1, IRX2, TIMP3, and PAX6. $C A L C A$ is known to encode a peptide hormone that plays a role in maintenance of calcium levels in blood serum and $\mathrm{T}$-and $\mathrm{B}$-cell regulation in certain malignancies, which is frequently methylated in multiple types of cancer [16,17]. CDH1 is a classical cadherin from the cadherin superfamily, which encodes a calcium dependent cell-cell adhesion protein. Epigenetic inactivation of $\mathrm{CDH} 1$ is thought to contribute to progression in cancer by increasing proliferation, invasion, and/or metastasis [18]. DAPK1 encodes a structurally unique calcium/calmodulin-dependent serine/threonine kinase which acts as a positive regulator of apoptosis. It is frequently methylated in human cancers as a tumor suppressor gene [19]. IRX2 is a member of the Iroquois homeobox transcription factor family, which is involved in developmental pattern formation in multiple organs such as the brain and heart [20]. It is highly specific for tumor-associated methylation, and little or no methylation is found in nonmalignant lung tissue [21]. TIMP3 is an angiogenesis inhibitor, and its epigenetic inactivation is associated with neovascularization and invasion in human malignancy [22]. PAX6, a transcription factor, has currently been suggested to function as a tumor suppressor in glioblastoma and to act as an early differentitation marker for neuroendocrine cells [23], which is

Table 5 Promoter methylation in NSCLC-multivariable models assessing smoking history, histologic type, lymph node metastasis, and pleural indentation $\left(\mathrm{OR}^{\dagger}\right.$ and $\left.95 \% \mathrm{Cl}\right)$

\begin{tabular}{lcccc}
\hline Genes & Smoking history & SCC vs. ADC & Lymph node metastasis & Pleural indentation \\
\hline CALCA & $1.07(0.40-2.88)$ & $2.66(0.85-8.32)$ & $1.43(0.46-4.41)$ & $2.19(0.61-7.79)$ \\
\hline CDH1 & $0.98(0.37-2.58)$ & $6.77(1.71-26.8)^{*}$ & $0.78(0.29-2.13)$ & $5.27(1.27-21.9)^{*}$ \\
\hline DAPK1 & $0.83(0.19-3.73)$ & $10.7(2.16-52.6)^{*}$ & $3.07(0.32-29.4)$ & $6.98(1.06-45.8)^{*}$ \\
\hline IRX2 & $0.69(0.26-1.83)$ & $6.38(1.77-23.0)^{*}$ & $0.85(0.31-2.33)$ & $3.89(1.01-15.0)^{*}$ \\
\hline TIMP3 & $0.78(0.30-2.02)$ & $3.37(1.03-11.0)^{*}$ & $1.75(0.65-4.75)$ & $2.66(0.77-9.16)$ \\
\hline PAX6 & $0.67(0.21-2.08)$ & $1.82(0.50-6.57)$ & $0.77(0.25-2.38)$ & $2.66(0.58-12.3)$ \\
\hline
\end{tabular}

† OR: odds ratio with $95 \%$ confidence interval, adjusted for multiple comparisions.

* Significant at $P<0.05$. 
frequently methylated in human cancers [21,24]. Similarly, our findings also showed that 3 of 6 genes had significantly higher methylation level in tumor tissues than nonmalignant lung tissues, including CALCA, CDH1, and PAX6 genes. Importantly, with $100 \%$ diagnostic specificity, excellent sensitivity, ranging from 44.9 to $84.1 \%$, was found for each of the 6 genes. The high specificity and frequency of these methylation markers make them excellent candidates for future applications developed for early diagnosis and prognosis evaluation of lung cancer.

Given smoking plays the central role in lung cancer development, it is somewhat surprising that we did not find significant association between promoter methylation of most genes and smoking history, in agreement with most studies [25-28]. However, several previous studies have reported aberrant DNA methylation of tumor-related genes was associated with tobacco smoking [29-32]. It is possible that lung cancer as a result of tobacco smoking is a complex disease with many unique genetic and epigenetic features. Better understanding of the molecular mechanisms underlying this disease would undoubtedly improve the outcomes of patients with smoking-associated lung cancer.

Our findings of substantial differences in promoter methylation depending on histologic typing of NSCLC have been reported to some degree in the literatures. Unlike what observed in the present study, a number of others have noted that adenomatous polyposis coli $(A P C)$, cyclin D2 (CCND2), potassium voltagegated channel, subfamily $\mathrm{H}$ (eag-related), member 5 $(\mathrm{KCNH} 5)$, and runt-related transcription factor 2 (RUNX2) genes were significantly more frequently in ADC compared to SCC [33-36]. Similar to the present study, although no statistical significance was observed, promoter methylation of DAPK1 gene was detected with higher frequency in SCC compared to ADC [36]. Conversely, there was not significant difference in promoter methylation of $C D H 1$ gene between SCC and $\mathrm{ADC}$ in this literature [36]. Anyway, we believe that our findings that promoter methylation of several genes is more frequent in SCC compared to ADC, particularly IRX2 gene, are new to the literature. Moreover, methylation level of DAPK1 and CALCA genes was significantly associated with lymph node metastasis and invasion/adhesion, suggesting that methylation degree of these genes might contribute to oncologic outcomes of NSCLC patients.

A very recent study showed that a number of important differences in frequency of promoter methylation in females compared to males, suggesting that promoter methylation is associated with gender [36]. However, these substantial differences have not been consistently noted in the previous literatures [35,37-39]. Similarly, promoter methylation was also not significantly associated with gender in the present study. It is possible that the differences in the promoter methylation associated with gender may be related to the geographical or cultural differences in carcinogen exposures, including cigarette smoking, dietary factors, occupational and environmental chemical exposure [40-42]. The discrepant results might also have been due to genetic differences of the study populations. A previous study indicated that patients harboring functional polymorphic variants of glutathione S-transferase pi 1 (GSTP1) had a higher risk of promoter hypermethylation of O-6methylguanine-DNA methyltransferase (MGMT) gene [43], suggesting that functional variants in the genes involved in the folate metabolism, DNA methylation, carcinogen metabolosim and the repair of methylation may play an important role in the susceptibility to promoter methylation. However, it is possible that these differences are attributable to chance as a result of the relatively small number of the study subjects examined. Therefore, further study with more subjects will be needed.

Interestingly, multivariable analyses revealed that the promoter methylation of a number of genes had signficant higher frequency in patients with pleural indentation compared with without pleural indentation, suggesting that promoter methylation may be a potentially increased risk for pleural indentation of NSCLC patients. Pleural indentation is a well-known imaging sign on chest computed tomography $(\mathrm{CT})$ that suggests a possible pleural invasion by peripheral NSCLC, particularly ADC $[44,45]$. A previous study showed that pleural involvement was significantly correlated with a poor prognosis in NSCLC, suggesting that pleural involvement may be one of most important factors to affect on the prognosis of NSCLC [46]. Although the degree of pleural invasion is clinically important, the accurate preoperative evaluation is sometimes difficult. $\mathrm{CT}$ and magnetic resonance imaging (MRI) are usually used in the evaluation of tumor extent, and diagnosis of chest wall invasion, pleural dissemination and pleural effusion can be easily made preooperatively by this way [47]. However, pleural dissemination and/or pleural effusion, which were not documented preoperatively, were sometimes revealed during operation. In addition, the accruate visceral pleural invasion can not be made with preoperative CT or MRI. In the present study, our findings suggested that promoter methylation of certain genes can increase the risk of pleural indentation in NSCLC. DNA methylation is the earliest and most frequent molecular events in human tumorigenesis. Detection of aberrant methylation using some high-senstive approaches can be thus used to predict and evaluate the pleural invovlement in NSCLC. 


\section{Conclusion}

In summary, in the present study, we found a panel of methylated genes that differentiate tumor tissues from nonmalignant lung tissues, which was strongly associated with clinicopathologic characteristics of NSCLC. Importantly, our data first revealed that promoter methylation may be a potentially increased risk factor for pleural indentation of NSCLC patients.

\section{Additional material}

Additional file 1: Table S1. Association of the level of promoter methylation with age, pack-years, tumor size and histoligic stage in NSCLC

\section{Acknowledgements}

This work was supported by the National Natural Science Foundation of China (No. 30901459 and 30973372) and the Fundamental Research Funds for the Central Universities.

\section{Author details}

${ }^{1}$ Department of Endocrinology, The First Affiliated Hospital of Xi'an Jiaotong University College of Medicine, Xi'an 710061, the People's Republic of China. ${ }^{2}$ Department of Pathology, The First Affiliated Hospital of China Medical University, Shenyang 110001, the People's Republic of China.

\section{Authors' contributions}

$\mathrm{MJ}$ and $\mathrm{PH}$ conceived and designed the experiments. MJ and $\mathrm{YZ}$ performed the experiments. MJ and $\mathrm{PH}$ collected the samples and analyzed the data. $\mathrm{BS}$ and $\mathrm{PH}$ contributed reagents/materials/analysis tools. PH Wrote the paper. All authors are in agreement with the content of the manuscript and this submission.

\section{Competing interests}

The authors declare that they have no competing interests.

Received: 27 April 2011 Accepted: 4 June 2011 Published: 4 June 2011

\section{References}

1. Bray FI, Devesa SS: Cancer burden in the year 2000. The global picture. Eur J Cancer 2001, 37(Suppl 8):S4-66.

2. Jemal A, Siegel R, Ward E, Hao Y, Xu J, Thun MJ: Cancer statistics, 2009. CA Cancer J Clin 2009, 59:225-49.

3. Song F, He M, Li H, Qian B, Wei Q, Zhang W, Chen K, Hao X: A cancer incidence survey in Tianjin: the third largest city in China-between 1981 and 2000. Cancer Causes Control 2008, 19:443-50.

4. Yang L, Parkin DM, Li LD, Chen YD, Bray F: Estimation and projection of the national profile of cancer mortality in China: 1991-2005. Br J Cancer 2004, 90:2157-66.

5. Hoffman PC, Mauer AM, Vokes EE: Lung cancer. Lancet 2000, 355:479-85.

6. Schwartz AG, Prysak GM, Bock CH, Cote ML: The molecular epidemiology of lung cancer. Carcinogenesis 2007, 28:507-18

7. Hung RJ, McKay JD, Gaborieau V, Boffetta P, Hashibe M, Zaridze D, Mukeria A, Szeszenia-Dabrowska N, Lissowska J, Rudnai P, Fabianova E, Mates D, Bencko V, Foretova L, Janout V, Chen C, Goodman G, Field JK, Liloglou T, Xinarianos G, Cassidy A, McLaughlin J, Liu G, Narod S, Krokan HE, Skorpen F, Elvestad MB, Hveem K, Vatten L, Linseisen J, et al: A susceptibility locus for lung cancer maps to nicotinic acetylcholine receptor subunit genes on 15q25. Nature 2008, 452:633-7.

8. Thorgeirsson TE, Geller F, Sulem P, Rafnar T, Wiste A, Magnusson KP, Manolescu A, Thorleifsson G, Stefansson H, Ingason A, Stacey SN, Bergthorsson JT, Thorlacius S, Gudmundsson J, Jonsson T, Jakobsdottir M, Saemundsdottir J, Olafsdottir O, Gudmundsson $\sqcup$, Bjornsdottir G, Kristjansson K, Skuladottir H, Isaksson HJ, Gudbjartsson T, Jones GT, Mueller T, Gottsäter A, Flex A, Aben KK, de Vegt F, et al: A variant associated with nicotine dependence, lung cancer and peripheral arterial disease. Nature 2008, 452:638-42.

9. Risch A, Plass C: Lung cancer epigenetics and genetics. Int J Cancer 2008, 123:1-7.

10. Jones PA, Baylin SB: The fundamental role of epigenetic events in cancer Nat Rev Genet 2002, 3:415-28

11. Esteller M: Cancer epigenomics: DNA methylomes and histonemodification maps. Nat Rev Genet 2007, 8:286-98.

12. Jones PA, Laird PW: Cancer epigenetics comes of age. Nat Genet 1999 21:163-7.

13. Esteller M, Corn PG, Baylin SB, Herman JG: A gene hypermethylation profile of human cancer. Cancer Res 2001, 61:3225-9.

14. Hou P, Ji M, Xing M: Association of PTEN gene methylation with genetic alterations in the phosphatidylinositol 3-kinase/AKT signaling pathway in thyroid tumors. Cancer 2008, 113:2440-7.

15. Hu S, Liu D, Tufano RP, Carson KA, Rosenbaum E, Cohen Y, Holt EH, Kiseljak-Vassiliades K, Rhoden KJ, Tolaney S, Condouris S, Tallini G, Westra WH, Umbricht CB, Zeiger MA, Califano JA, Vasko V, Xing M: Association of aberrant methylation of tumor suppressor genes with tumor aggressiveness and BRAF mutation in papillary thyroid cancer. Int J Cancer 2006, 119:2322-9.

16. Brait $M$, Begum S, Carvalho AL, Dasgupta S, Vettore AL, Czerniak B, Caballero OL, Westra WH, Sidransky D, Hoque MO: Aberrant promoter methylation of multiple genes during pathogenesis of bladder cancer. Cancer Epidemiol Biomarkers Prev 2008, 17:2786-94.

17. Paixão VA, Vidal DO, Caballero OL, Vettore AL, Tone LG, Ribeiro KB, Lopes LF: Hypermethylation of $\mathrm{CpG}$ island in the promoter region of CALCA in acute lymphoblastic leukemia with central nervous system (CNS) infiltration correlates with poorer prognosis. Leuk Res 2006, 30:891-4.

18. Berx G, van Roy F: Involvement of members of the cadherin superfamily in cancer. Cold Spring Harb Perspect Biol 2009, 1:a003129.

19. Ahmed IA, Pusch CM, Hamed T, Rashad H, Idris A, El-Fadle AA, Blin N: Epigenetic alterations by methylation of RASSF1A and DAPK1 promoter sequences in mammary carcinoma detected in extracellular tumor DNA. Cancer Genet Cytogenet 2010, 199:96-100.

20. Christoffels VM, Keijser AG, Houweling AC, Clout DE, Moorman AF: Patterning the embryonic heart: identification of five mouse Iroquois homeobox genes in the developing heart. Dev Biol 2000, 224:263-74.

21. Rauch TA, Zhong X, Wu X, Wang M, Kernstine KH, Wang Z, Riggs AD, Pfeifer GP: High-resolution mapping of DNA hypermethylation and hypomethylation in lung cancer. Proc Natl Acad Sci USA 2008, 105:252-7.

22. Bachman KE, Herman JG, Corn PG, Merlo A, Costello JF, Cavenee WK, Baylin SB, Graff JR: Methylation-associated silencing of the tissue inhibitor of metalloproteinase-3 gene suggest a suppressor role in kidney, brain, and other human cancers. Cancer Res 1999, 59:798-802.

23. Robson EJ, He SJ, Eccles MR: A PANorama of PAX genes in cancer and development. Nat Rev Cancer 2006, 6:52-62.

24. Hellwinkel OJ, Kedia M, Isbarn H, Budäus L, Friedrich MG: Methylation of the TPEF-and PAX6-promoters is increased in early bladder cancer and in normal mucosa adjacent to pTa tumours. BJU Int 2008, 101:753-7.

25. Belinsky SA, Nikula K, Palmisano WA, Michels R, Saccomanno G, Gabrielson E, Baylin SB, Herman JG: Aberrant methylation of p16(INK4a) is an early event in lung cancer and a potential biomarker for early diagnosis. Proc Natl Acad Sci USA 1998, 95:11891-6.

26. Kersting M, Friedl C, Kraus A, Behn M, Pankow W, Schuermann M: Differential frequencies of p16(INK4a) promoter hypermethylation, p53 mutation, and K-ras mutation in exfoliative material mark the development of lung cancer in symptomatic chronic smokers. J Clin Oncol 2000, 18:3221-9.

27. Kim DH, Nelson HH, Wiencke JK, Zheng S, Christiani DC, Wain JC, Mark EJ, Kelsey KT: p16(INK4a) and histology-specific methylation of CpG islands by exposure to tobacco smoke in non-small cell lung cancer. Cancer Res 2001, 61:3419-24.

28. Toyooka S, Maruyama R, Toyooka KO, McLerran D, Feng Z, Fukuyama Y, Virmani AK, Zochbauer-Muller S, Tsukuda K, Sugio K, Shimizu N, Shimizu K, Lee H, Chen CY, Fong KM, Gilcrease M, Roth JA, Minna JD, Gazdar AF: Smoke exposure, histologic type and geography-related differences in the methylation profiles of non-small cell lung cancer. Int J Cancer 2003, 103:153-60.

29. Kim DH, Kim JS, Ji YI, Shim YM, Kim H, Han J, Park J: Hypermethylation of RASSF1A promoter is associated with the age at starting smoking and a 
poor prognosis in primary non-small cell lung cancer. Cancer Res 2003, 63:3743-6.

30. Toyooka S, Suzuki M, Tsuda T, Toyooka KO, Maruyama R, Tsukuda K, Fukuyama Y, lizasa T, Fujisawa T, Shimizu N, Minna JD, Gazdar AF: Dose effect of smoking on aberrant methylation in non-small cell lung cancers. Int J Cancer 2004, 110:462-4.

31. Kim JS, Kim H, Shim YM, Han J, Park J, Kim DH: Aberrant methylation of the FHIT gene in chronic smokers with early stage squamous cell carcinoma of the lung. Carcinogenesis 2004, 25:2165-71.

32. de Fraipont F, Moro-Sibilot D, Michelland S, Brambilla E, Brambilla C, Favrot MC: Promoter methylation of genes in bronchial lavages: a marker for early diagnosis of primary and relapsing non-small cell lung cancer. Lung Cancer 2005, 50:199-209.

33. Harden SV, Tokumaru Y, Westra WH, Goodman S, Ahrendt SA, Yang SC, Sidransky D: Gene promoter hypermethylation in tumors and lymph nodes of stage I lung cancer patients. Clin Cancer Res 2003, 9:1370-5.

34. Gu J, Berman D, Lu C, Wistuba II, Roth JA, Frazier M, Spitz MR, Wu X: Aberrant promoter methylation profile and association with survival in patients with non-small cell lung cancer. Clin Cancer Res 2006, 12:7329-38.

35. Yanagawa N, Tamura G, Oizumi H, Kanauchi N, Endoh M, Sadahiro M, Motoyama T: Promoter hypermethylation of RASSF1A and RUNX3 genes as an independent prognostic prediction marker in surgically resected non-small cell lung cancers. Lung Cancer 2007, 58:131-8.

36. Hawes SE, Stern JE, Feng Q, Wiens LW, Rasey JS, Lu H, Kiviat NB, Vesselle H: DNA hypermethylation of tumors from non-small cell lung cancer (NSCLC) patients is associated with gender and histologic type. Lung Cancer 2010, 69:172-9.

37. Nakata S, Sugio K, Uramoto H, Oyama T, Hanagiri T, Morita M, Yasumoto K: The methylation status and protein expression of CDH1, p16(INK4A), and fragile histidine triad in nonsmall cell lung carcinoma: epigenetic silencing, clinical features, and prognostic significance. Cancer 2006, 106:2190-9.

38. Kim DS, Kim MJ, Lee JY, Kim YZ, Kim EJ, Park JY: Aberrant methylation of $\mathrm{E}$-cadherin and $\mathrm{H}$-cadherin genes in nonsmall cell lung cancer and its relation to clinicopathologic features. Cancer 2007, 110:2785-92.

39. Vaissiere T, Hung RJ, Zaridze D, Moukeria A, Cuenin C, Fasolo V, Ferro G, Paliwal A, Hainaut P, Brennan P, Tost J, Boffetta P, Herceg Z: Quantitative analysis of DNA methylation profiles in lung cancer identifies aberrant DNA methylation of specific genes and its association with gender and cancer risk factors. Cancer Res 2009, 69:243-52.

40. Issa JP, Baylin SB, Belinsky SA: Methylation of the estrogen receptor CpG island in lung tumors is related to the specific type of carcinogen exposure. Cancer Res 1996, 56:3655-8.

41. Moore LE, Huang WY, Chung J, Hayes RB: Epidemiologic considerations to assess altered DNA methylation from environmental exposures in cancer. Ann N Y Acad Sci 2003, 983:181-96.

42. Vuillemenot BR, Pulling LC, Palmisano WA, Hutt JA, Belinsky SA: Carcinogen exposure differentially modulates RAR-beta promoter hypermethylation, an early and frequent event in mouse lung carcinogenesis. Carcinogenesis 2004, 25:623-9.

43. Gilliland FD, Harms HJ, Crowell RE, Li YF, Willink R, Belinsky SA: Glutathione S-transferase P1 and NADPH quinone oxidoreductase polymorphisms are associated with aberrant promoter methylation of P16(INK4a) and O (6)-methylguanine-DNA methyltransferase in sputum. Cancer Res 2002, 62:2248-52.

44. Shapiro R, Wilson GL, Yesner R, Shuman $H$ : A useful roentgen sign in the diagnosis of localized bronchioloalveolar carcinoma. Am J Roentgenol Radium Ther Nucl Med 1972, 114:516-24.

45. Kuhlman JE, Fishman EK, Kuhajda FP, Meziane MM, Khouri NF, Zerhouni EA, Siegelman SS: Solitary bronchioloalveolar carcinoma: CT criteria. Radiology 1988, 167:379-82.

46. Li M, Ito H, Wada H, Tanaka F: Pit-fall sign on computed tomography predicts pleural involvement and poor prognosis in non-small cell lung cancer. Lung Cancer 2004, 46:349-55.

47. Murayama S, Murakami J, Yoshimitsu K, Torii Y, Ishida T, Masuda K: CT diagnosis of pleural dissemination without pleural effusion in primary lung cancer. Radiat Med 1996, 14:117-9.

doi:10.1186/1746-1596-6-48

Cite this article as: Ji et al:: Association of promoter methylation with histologic type and pleural indentation in non-small cell lung cancer (NSCLC). Diagnostic Pathology 2011 6:48.

\section{Submit your next manuscript to BioMed Central and take full advantage of:}

- Convenient online submission

- Thorough peer review

- No space constraints or color figure charges

- Immediate publication on acceptance

- Inclusion in PubMed, CAS, Scopus and Google Scholar

- Research which is freely available for redistribution

Submit your manuscript at www.biomedcentral.com/submit
Biomed Central 